Competing interest: CSF is employed by Yahoo!, the for-profit internet search engine that $\mathrm{CDC}$ had a contract with during this campaign. CSF's professional compensation includes Yahoo! stock. The results of this study could potentially benefit Yahoo! by attracting new advertisers.

Ethical approval: Not needed.

1 Yahoo! Yahoo! First quarter 2003 financial highlights. Sunnyvale, CA Yahoo!, 2003
2 Bannan KJ. Search engines' positive results drive price wars. $B$ to $B$ 2003:88(10 Mar): 18-20.

3 Krishnamurthy S. Deciphering the internet advertising puzzle. Marketing Management 2000;9:34-9.

4 Centers for Disease Control and Prevention. Donated television airplay of colorectal cancer education public service announcementsUnited States, 1999-2002. MMWR Morb Mortal Wkly Rep 2003;52: 196-9.

5 Jorgensen CM, Gelb CA, Merritt TL, Seeff LC. Observations from the CDC: CDC's Screen for life: a national colorectal cancer action campaign. $J$ Women's Health Gend Based Med 2001;10:417-22.

\title{
Critical care medicine mailing list: growth of an online forum
}

\author{
Anthony L DeWitt, Scott R Gunn, Phil Hopkins, Stephen Streat
}

Bartimus,

Frickleton,

Robertson \& Obetz

200 Madison, Suite

1000, Jefferson City,

MO 65101, USA

Anthony L DeWitt

attorney

Department of

Critical Care

Medicine,

University of

Pittsburgh Medical

Center, 646B Scaife

Hall, 3550 Terrace

Street, Pittsburgh,

PA 15261

Scott R Gunn

associate professor

Faculty of Medicine

Imperial College,

London W12 0NN

Phil Hopkins

MRC clinical fellow

in infectious diseases

Department of

Critical Care

Medicine, Auckland

City Hospital,

Private Bag 92-024,

Auckland 1003

New Zealand

Stephen Streat

intensivist

Correspondence to:

S R Gunn

gunnsr@ccm.

upmc.edu

BMJ 2004;328:1180
In 1994 Dr David Crippen created the critical care medicine mailing list to provide an internet forum for healthcare professionals. The list was the first of its kind dedicated to the discussion of the holistic care of patients in intensive care units. The list's website logs about 10000 hits a year, and its membership includes over 1000 physicians, nurses, pharmacists, researchers, and allied healthcare professionals across six continents. ${ }^{1}$

\section{Benefits of information sharing}

Because of its accessibility, the list has given voice to a diverse group of multidisciplinary healthcare providers for the first time. This networking potential facilitates the reinforcement of similar ideas and standards of practice. Other unforeseen applications have developed. During the recent outbreak of severe acute respiratory syndrome (SARS) in Asia, list members initially broke the emerging story from Hong Kong in real time. ${ }^{2}$ The list has produced other tangible results. Crippen and others recently published the first multinational reference on end of life care using list members as resources. ${ }^{3}$ We have identified six peer reviewed articles that have resulted from interactions on the list. ${ }^{4-9}$

\section{Difficulties associated with information sharing}

Information security

The formation of any electronic forum introduces security and privacy issues. The list is a potential target for commercial or political organisations. During the SARS outbreak, many media organisations became subscribers to the list. ${ }^{2}$ Members were forced to become more circumspect in their observations to avoid media manipulation. The potential for spontaneous, unbiased information was diluted commensurately. The Caldicott report has tried to develop general principles of confidentiality in electronic media. ${ }^{10}$

\section{Medical legal concerns}

The internet is an undefined area in relation to medical liability. For example, if a doctor solicits an online opinion on a patient's care, this action may create an agency on behalf of the patient and subject the doctor who offers that opinion to liability. ${ }^{11}$ Likewise, if a doctor offers an opinion on standard of care, that statement may be archived and accessible by others. If that doctor is later sued for negligence or designated as an expert in a negligence case, the opinion they gave earlier in the context of a different case may have impeachment value. ${ }^{12}$

\section{The future}

Online mail resources continue to grow. Future directions might encompass multinational databases for evaluating new treatments or reporting critical incidents. As these online services grow, critical evaluation and validation of opinions may be necessary. Other possibilities for educational development might include virtual conferences, workshops, or the rotation of list members between different geographical areas.

The Critical Care Medicine Listserv can be found at www.pitt.edu/ crippen. All the authors are members of the list. Contributors: All authors collaboratively conceived the idea for the article; SRG, PH, and ALDeW did the literature search; and ALDeW, PH, and SS wrote the article. SRG is the guarantor. Funding: No special funding.

Competing interests: None declared. cal Care Clinics 1999:15:605-14.

A doctor in Hong Kong deals with SARS. 30 April 2003. www.abc.net.au/ abcasiapacific/focus/stories/s847149.htm (accessed 24 Apr 2004).

3 Crippen D, Kilcullen J, Kelly D, eds. Three patients-international perspective on intensive care at the end of life. Boston: Kluwer Academic, 2002.

Nagappan R, Riddell T. Pyridoxine therapy in a patient with severe hydrazine sulfate toxicity. Crit Care Med 2000;28:2116-8.

5 Campbell D, Steinmann M, Porayko L. Nitric oxide and high frequency jet ventilation in a patient with bilateral bronchopleural fistulae and ARDS. Can J Anaesth 2000;47(1):53-7.

6 Porayko LD, Butler R. Perioperative resuscitation knowledge base. Can J Porayko LD, Butler R. Peri

Porayko LD, Gelb A. Antihypertensive therapy in stroke patients. Eur J Anaesth 1998;15(suppl):48-9.

8 Hopkins P, Sriskandan. S. Gram-positive bacterial infection in severe sepsis. Clin Intensive Care 2002;13:147-60.

9 Cassell J, Buchman TG, Streat S, Stewart RM. Surgeons, intensivists, and the covenant of care: administrative models and values affecting care at the end of life. Crit Care Med 2003;31:1551-7.

10 Caldicott Committee. Report on the review of patient-identifiable information. London: NHS Executive, 1997.

11 Adams v Via Christi Regional Medical Center [2001]. In: Kansas Reporter:824. Kansas Supreme Court.

12 Wild MD v Rarig [1975]. In: Northeastern Reporter:775. 2nd ed. Minnesota Supreme Court. 